\title{
Identifying the aspects of organizational culture: a study of Indian banking industry
}

\author{
Pooja Singh Negi and Ramesh Chandra Dangwal \\ Department of Commerce, \\ Hemwati Nandan Bahuguna Garhwal University - Birla Campus, Srinagar, India
}

\begin{abstract}
Purpose - The purpose of the present study is to identify the core cultural aspects perceived by the executives of public, private and foreign banks in India.

Design/methodology/approach - Of the 124 responses, 96 usable responses were assessed from middle and lower level managers. Qualitative content analysis and deconstruction method were used to identify the perceived cultural aspects.

Findings - Interestingly, managers of Indian banking industry stated that cultural aspects of their banks possess good work and working environment, prefer people, management, experience and promotions in comparison to other factors like policy, bonus, market, commitment, project, etc. It is also noted that cultural aspects of banks prefer learning, training and team working.

Practical implications - Assessment of the perception of managers toward their culture will foster the banks to develop integral subculture and to achieve the long-term organizational goals.

Originality/value - The study analyze the cultural aspects in Indian banking industry qualitatively, based on executives characteristics. This qualitative analysis helps to find out more contemporary and prevailing factors of banks.
\end{abstract}

Keywords Culture, Indian banking industry, Public, Private, Foreign banks

Paper type Conceptual paper

\section{Introduction}

India is one of the largest economic giants reconnoitering with omni-channel touch facts, scientific resources and reach to a major part of the population. Scams and swindles in banks affect the nation (Gurnani, 2015), and these cons require organizational experts to differentiate synergetic effects within a business organization (Harung et al., 1999). Since banks are service-based businesses, it is the healthy cultural environment that can feature the good financial services and assist better services to customers. Although stability has been observed in financial and economic conditions (RBI, 18), the cultural process of banks needs effective and improved governance (Diwanji, 2018). Growing levels of such trickeries in banks require greater emphasis on researching the role of organization cultural aspects.

Existing, cultural literature lacks an influential qualitative analysis with there being a larger role for organizational sustainability (Negi and Dangwal, 2019). In response, banks have become very thoughtful about the lending segment (Antony and Sanjai, 2018), and steps are being taken to ensure an optimistic culture (Altstedter and Nag, 2018). The human resources of banks need complete renovation (Antony and Sanjai, 2018) as it has a strong influence on business culture, principles and performance standards (Catana and Catana, 2010). The field of organizational culture is currently developing, but the dimensions are

(C) Pooja Singh Negi and Ramesh Chandra Dangwal. Published in PSU Research Review. Published by Emerald Publishing Limited. This article is published under the Creative Commons Attribution (CC BY 4.0) licence. Anyone may reproduce, distribute, translate and create derivative works of this article (for both commercial and non-commercial purposes), subject to full attribution to the original publication and authors. The full terms of this licence may be seen at http://creativecommons.org/licences/by/4.0/legalcode

Received 31 March 2021 Revised 6 May 2021 22 June 2021

Accepted 13 August 2021 organizational culture 
relatively limited and need improvements to provide a sustainable functional setting (Negi et al., 2019).

Culture in banking organizations has been drawing interest among researchers around the domain (i.e. Singh, 2011; Mellor, 2015; Peters and Waterman, 1982; Kilmann et al., 1985; Schein, 1990). The first intention of this study is to identify the core cultural aspects in the banking industry, as practiced by executives. The subsequent aim of the existing study is to also check the least preferable dimensions that have been ignored. To my knowledge, very few studies with the exception of Nazir (2005), scrutinized organizational culture within banks, assume that some common dimensions tend to measure perceptions in limited ways (Calciolari et al., 2018). However, seeing organizational culture as uniform among all executives is very basic (Hofstede, 1994).

\section{Literature review \\ Organizational culture}

The concept of organizational culture has become prevalent since the 1980s (Pettigrew, 1979). Organizational culture has gained lot of attention in the organizational behavior (Peters, 1982) and recently considered as one of the evolving conception for empirical research (Adler, 1989; Schein, 1990; Denison, 1990; Gordon and Tomaso, 1992; Hatch, 1993; Hofstede, 1994; Bloor and Dawson, 1994). The cultural term has been introduced by social anthropologists (Kotter and Heskett, 1992; Taylor, 2008) and explains the differences among managerial results qualitatively (Pettigrew, 1979). The study of Sanjaghi et al. (2014) explored several factors for Iran Industrial Research Organization (IIRO). These factors are cooperativeness, innovativeness, consistency and effectiveness. The results divulged that these exemplifies of "organizational culture" are appropriate, and environmental responsiveness and knowledge management both are necessary in today's competitive environment.

Other significant research of Negi and Dangwal (2019) observed that absence of adequate literature limits their investigation. Hence, we suggest that researchers should consider different constructs for further analysis. Likewise, Negi et al. examine the sustainabilityoriented organizational culture of selected service sector companies and advice to inculcate more contemporary variables. On the other hand, Aboramadan et al. (2019) scrutinize the links between organizational culture, innovation and banks' performance in Palestine. The study recommended to consider the qualitative approaches to provide better elucidation of the organizational culture. Additionally, different aspects of organizational culture can make study more interesting. In contrast to this, Pathardikar and Sahu (2011) reflect the status of the culture in the public sector organizations and evidently confirm the need for audits of HR practices in the organization. The study also suggests that research in private organizations differs in culture and HR practices from that of the public sector units in India.

Leveson et al. (2009) suggest that in future, research should reconnoiter the perception of management to explore the direct and indirect variables of culture. Besides this, access to informal networks variable could refine cultural differences and not to some other dimensions of variance. Unfortunately, the use of questionnaires showed incapability to yield more affluent data in comparison to interviews. From Akhavan et al. (2014) perspective, organizational culture impacts environmental responsiveness capability in selected IIRO. The study also found that scale for organizational culture does not reflect the actual situation in Iran due to specific national setting. Although, Riivari et al. (2012) showed a positive link between the culture and innovativeness. At the same time, authors preferred for qualitative study for richer and more in-depth understanding of this relationship. Likewise, Bamel et al. (2011) empirically examines the relationship of dimensions of organizational climate with managerial effectiveness in Indian organizations. The study considered only a few dimensions of organizational climate (organizational process, behavior role clarity and 
communication, results-reward and interpersonal relationships) and suggested exploring some different variables to predict managerial performance.

Extensive literature review depicts that various empirical examinations have been taken up with reference to organizational culture. Several studies determine culture with performance, commitment, satisfaction and personal behavioral aspects (Ojo, 2009; Dwivedi et al., 2014; Kelepile, 2015; Tripathi and Tripathi, 2009). The combined concept of qualitative analysis on cultural aspects has remained unnoticed. The purpose of the present study is to analyze the opinions and perception of executives' of public, private and foreign banks qualitatively. The analysis of this conceptual study is organized in such a way so that it can enlarge the limited literature. Subsequently, a qualitative approach was preferred to apprehend the cultural perceptions on the subject of their effectiveness. Thus, the gaps identified above unquestionably suggest that there is a need to investigate these contemporary concepts i.e. organizational culture in Indian banking system to support the qualitative growth of the economy.

\section{Methodology}

Sample and procedure

Owing to high population density in Delhi and NCR region, only 15 of the 99 banks have been put to study. A sample of five banks each from the public and private sector has been selected by their market capitalization listed on Bombay Stock Exchange, whereas five foreign banks have been selected on their quality service basis; 150 questionnaires were circulated to the middle- and top-level managers. A total of $124(82.6 \%)$ questionnaires were answered, but 96 $(64 \%)$ have been assessed, as they were completely filled.

Open-ended questions were analyzed to extract the contemporary characteristics of cultural patterns of managers. For this, managers were asked to mention their views about cultural aspects. First, the survey was carried out in the form of open-ended questions converted into transcripts and then analyzed during the stages of the investigation. For this, each transcript was summarized and studied manually. Then, in order to analyze more specifically, each transcript was coded based on their stated characteristics by using the NVivo software. After giving the demographic characteristics of managers under the closeended questions, the study presented qualitative content analysis and explained the most relevant and desirable cultural practices adopted by banks for their executives.

Thereafter, these transcripts were entered into categorical form manually. To safeguard the privacy of executives and to maintain their trust, their responses were categorized accordingly. The executives and their banks were mentioned by a specific code (numbers 1 to 15). These codes were imported into NVivo software and analyzed comprehensively. Following this, content analysis and deconstruction method were also used.

\section{Demographic characteristics of the respondents}

The study assessed 96 managers from public, private and foreign banks in India. Keeping in mind the availability of banks and population adequacy, the most populated cities, Delhi and $\mathrm{NCR}$, were selected for the survey. Of the total participants, $82.2 \%$ were male and $19.7 \%$ were female. Moreover, 59.3\% participants were from Delhi and the rest (40.6) were from NCR. Besides this, these two regions also contain maximum concentration of banks instead of others. The summarized details of managers are presented in Table 1. The identity of (name and branches) managers of public, private and foreign banks was kept confidential and anonymous.

\section{Conduction of survey}

Data are directly acquired by managers to draw out the original findings of the research. The questionnaires were distributed among managers in 15 different banks. Field survey enables 


\section{PRR}

\begin{tabular}{|c|c|c|c|}
\hline S. No. & Cultural aspects & Banks & Mangers referred (in Appendix) \\
\hline \multirow[t]{3}{*}{1} & \multirow{3}{*}{ Good work } & Public & $12,13,28$ \\
\hline & & Private & $5,14,16,22,31,35$ \\
\hline & & Foreign & $11,17,21,24$ \\
\hline \multirow[t]{3}{*}{2} & \multirow[t]{3}{*}{ Better working } & Public & $13,14,15,19$ \\
\hline & & Private & $15,22,24,31$ \\
\hline & & Foreign & $11,20,21,22$ \\
\hline \multirow[t]{3}{*}{3} & \multirow[t]{3}{*}{ Management and learning } & Public & $5,22,26,28,29,31$ \\
\hline & & Private & $5,11,28,31,32,35$ \\
\hline & & Foreign & $1,3,5,9,15,18,22,23,25,27$ \\
\hline \multirow[t]{3}{*}{4} & \multirow{3}{*}{ Training and promotion } & Public & $1,2,4,16,26,30$ \\
\hline & & Private & $1,2,5,7,34$ \\
\hline & & Foreign & $8,9,10,17,19$ \\
\hline \multirow[t]{3}{*}{6} & \multirow[t]{3}{*}{ Experience and knowledge } & Public & 2,31 \\
\hline & & Private & 1,3 \\
\hline & & Foreign & $3,8,12,15,21,24,25,27$ \\
\hline \multirow[t]{3}{*}{7} & \multirow[t]{3}{*}{ Cultural and career } & Public & $3,12,18,32$ \\
\hline & & Private & $8,9,12,13,17,20,21,22,23,25,29,31$ \\
\hline & & Foreign & $2,8,12,13,14,16,18,19,21,23,26,29$ \\
\hline \multirow[t]{3}{*}{8} & \multirow[t]{3}{*}{ People and staff } & Public & $16,21,24,25,27,30$ \\
\hline & & Private & $10,18,19,20,28$ \\
\hline & & Foreign & $1,4,5,7,19,23,24,26,28$ \\
\hline \multirow[t]{3}{*}{9} & \multirow[t]{3}{*}{ Commitment and completeness of jobs } & Public & 30 \\
\hline & & Private & $3,26,27,32$ \\
\hline & & Foreign & $2,7,8,19,28$ \\
\hline \multirow[t]{3}{*}{11} & \multirow[t]{3}{*}{ Project } & Public & 11 \\
\hline & & Private & $3,7,8$ \\
\hline & & Foreign & 11,12 \\
\hline \multirow[t]{3}{*}{13} & \multirow{3}{*}{ Friendly environment } & Public & 15,29 \\
\hline & & Private & $4,16,18,22,24$ \\
\hline & & Foreign & $1,11,20,26$ \\
\hline \multirow[t]{3}{*}{14} & \multirow[t]{3}{*}{ Expectation } & Public & 6,28 \\
\hline & & Private & $2,3,26,27,28,30,32,34$ \\
\hline & & Foreign & $4,5,7,12,28$ \\
\hline \multirow[t]{3}{*}{15} & \multirow{3}{*}{ Salary issue } & Public & $8,9,17,20,23$ \\
\hline & & Private & $6,7,33$ \\
\hline & & Foreign & 16 \\
\hline \multirow[t]{3}{*}{16} & \multirow{3}{*}{ Working pressure/hours/risk } & Public & 6,10 \\
\hline & & Private & $27,28,30$ \\
\hline & & Foreign & 10,13 \\
\hline
\end{tabular}

one to collect data personally within a short period (Sekaran, 2003; Zikmund and Babin, 2013) and protects the privacy of managers. For this, responses of managers and their banks were coded individually. Questionnaire consists of open-ended questions that provide more additional information about managers who may not have been apprehended in the closeended questions (Fowler and Cosenza, 2008). Moreover, managers used various proverbs, metaphors and various examples in their survey.

\section{Qualitative content analysis}

The contents were analyzed to make findings more replicable and valid (Krippendorff, 2012). The responses of managers (content) in the form of words were classified into texts (Burns and Grove, 2005). Then, classes are formed from texts (meaningful matter) to specific codes. In this study, conventional, directed and summative approaches were scrutinized to examine 
the textual data (Hsieh and Shannon, 2005). First, text data were categorized under the conventional approach.

In a directed approach, a wide review of literature was consulted to codify the texts. Finally, contents were compared and interpreted under a summative approach. All these three approaches possess identical analytical procedures divided in six major phases (Kaid and Wadsworth, 1989). In the present study, phases start with formulation of research questions, selection of sample, outlining categorization, defining and implementing codifications process and analysis of results with trustworthiness. The conventional approach (Hsieh and Shannon, 2005) of the qualitative content analysis (Kaid and Wadsworth, 1989; Burns and Grove, 2005; Krippendorff, 2012) has been followed sequentially; first, data had been collected with openended questions. Second, texts have been analyzed. Third, texts have been examined for categorization. Fourth, texts have been summarized and categorized. Fifth, encodings have been constructed from the texts of transcripts. Finally, texts have been analyzed, reviewed and characterized into codes to present the results. Furthermore, NVivo 10 software (Bazeley and Jackson, 2013) has been used to perform qualitative data analysis.

Furthermore, deconstruction method has been used to demystify the texts into meaningful conjectures. This method also helps to disclose the hidden constructs into meaningful presuppositions. The written texts were analyzed critically to make interpretation more centralized and focused.

\section{Validity of research}

The validity of qualitative research has been adequately followed and discussed briefly. No subsequent standard test for validation of qualitative research has been found in the literature in comparison to quantitative research. Centered on characteristics of research, five categories have been discussed to assess the validity of qualitative research (Maxwell, 1992). These categories are classified as following:

First, the study ensured descriptive validity by inculcating the plurality of responses of different executives of public, private and foreign banks in terms of organizational culture. The responses from several different executives confirm the accuracy of data as well (Maxwell, 1992; Johnson, 1997). Second, the interpretative validity has been followed with the help of open-ended questions based on organizational culture. The present study reports the respondents' response manually with meaningful understanding of events, entities and their performances (Maxwell, 1992). The researcher tries to analyze the executives' interpretation according to the sector of banks i.e. public, private and foreign banks. Third, theoretical validity allied with degree of consistency between theoretical explanations of qualitative research and data. In this study, categorization of the description of cultural patterns of managers is anticipated with content analysis. In order to attain theoretical validity, this analysis has referred to the frequency of texts stated in the openended questions. NVivo software has been used to analyze the additional information provided by executives of banks, which may not have been apprehended in the close-ended questions. The study identifies the new insights with those dimensions that are related to the organizational culture from executives' point of view. In terms of generalizability, identified new insights of this research can be applied universally. According to the ethical framework and judgments of evaluative validity, researchers try to apprehend and describe the data without any partial judgment. Fairness and objectivity have been maintained while analyzing the documented texts.

\section{Measures}

The open-ended questions consist of accurate outlooks, understanding and attitudes of the respondents on the related subjects. All responses were coded in the form of texts and analyzed conjointly. The word frequency criteria had been used to find out the words that were used by respondents more frequently. 

executives were from public sector banks, 35 were from private sector banks and 29 were from foreign banks. Precise and pertinent information have been stated by executives through several models and instances. In this segment, information was classified according to the category of banks representing the cultural characteristics. Based on preliminary analysis of the executive's views in the form of texts, information has been identified and then characterized. Other than the integrated view on cultural aspects of managers, this study also tracked the manager's individual approach to analyze their perceptions. For this, manager's textual data have been presented, which seemed to examine the insights into a qualitative way. Yet, opinions of managers of public, private and foreign banks were described sequentially in Table A1.

With the cultural description, the study identified several related and relevant characteristics. After the categorization, the numerical coding has been done in the NVivo software to analyze the executives' perception. Each characteristic has been presented in Table 1 . The findings of this analysis demonstrate that some exemplified characteristics are sustained by various executives'. Interestingly, these characteristics have been ignored in the existing review of literature. The study tries to consider more participants who could be placed in banking categories. Obviously, a larger number of participants help to analyze the supporting dimensions of executives. The word cloud (Figure 1) has been generated through open-ended questions, included in the questionnaires.

\section{Discussion}

The first identified characteristic signifies that banks are attached with the executives and provide them with a "good work" environment. This recognizing and comprehending characteristic of banks enables individuals' to boost their productivity. Good work factors also motivate employee retention in future. The second characteristic of this analysis ensures that executives of banks recognize "better working" instead of complexity. The better working environment reduces unpredictability and enhances expertise as well as perceptiveness. The third characteristic is "management and learning" which indicates that banks are providing adequate assistance and guidance to their executives. Being new or unexpected, learning and training assist executives to solve their problems that are different and unfamiliar to them. It also provides a stable and unwavering working environment to them. The fourth characteristic is more related to the efficiency of managers i.e. "training and promotion". Managers should motivate employees for new idea creation with rewarding, when necessary; they can also establish an environment where new ideas are openly and freely shared (Uzkurt et al., 2013). Culture of banks generally favors those executives who possess promotion as well as experience skills. This characteristic is also related to the term perceptiveness (experience and knowledge), which in turn helps them to solve their complexity at the workplace. The essence of culture is that the organization's members can find solutions to problems about internal integration, adaptation to environment and coordination through shared cultural values (Blackwell, 2006; Furnham and Gunter, 1993).

"Culture and career" is the fifth characteristic mentioned by executives in the open-ended questions. The executives of the public, private and foreign banks mentioned that culture and career are recognizable as well as relevant issues for them. Culture stable and operate business set-ups robustly (Schein, 1990). The executives of banks stated that (sixth characteristic) "people and staff" is a vital characteristic for them instead of salary and bonus. The essence of culture is that the organization's members can find solutions to problems about internal integration, adaptation to environment and coordination through shared cultural values (Blackwell, 2006; Furnham and Gunter, 1993).

Commitment and completeness of jobs are other highly preferred and remarkable aspects of executives. The other characteristics like knowledge, project, completeness of jobs and 

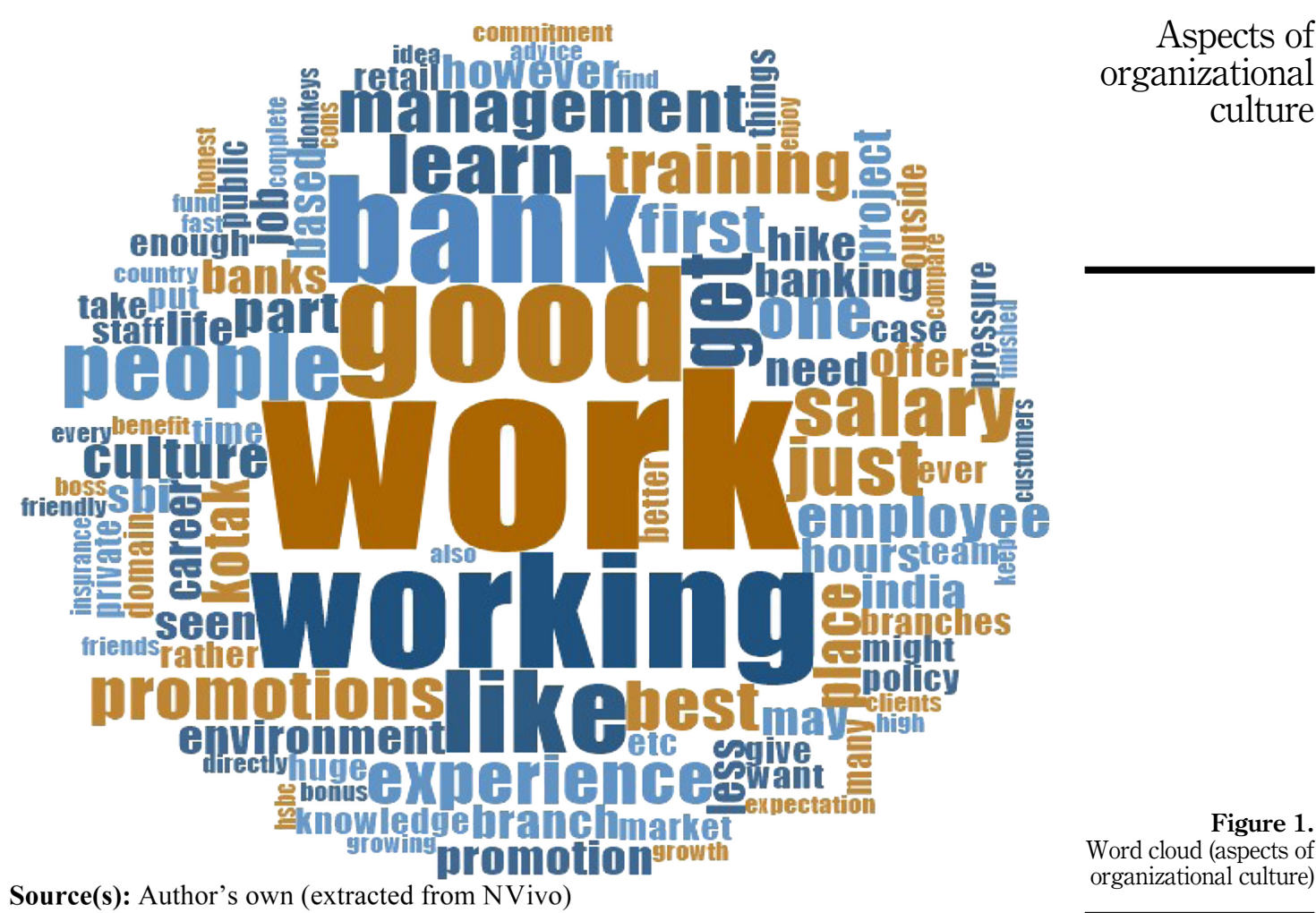

Figure 1.

Word cloud (aspects of organizational culture)

friendly environment are some most defined aspects among executives. On the other hand, factors like project and policy, friendly environment, expectation, salary issues and working pressure/hours/risk were also mentioned in the texts. The innovative culture of an organization recognizes and nurtures the uniqueness of its employees and empowers the managers to follow their vision (Uzkurt et al., 2013).

\section{Managerial implications, limitations and further research}

Negi and Dangwal (2020) observe that incorporation of qualitative study in the form of openended questions can explore finer points for effectiveness of managers. As a result, this paper identifies most contemporary aspects of organizational culture that enriched the functioning of executives in banks. These cultural aspects can be used by employers, professionals and practitioners for evaluating the culture in organizations. Therefore, it is imperative for firms to establish these aspects that guide the preferred behavior of executives. Furthermore, the study also recommends manifestation of a better promotion and training mechanism which mobilizes learning and boosts productivity. This study also suggests that management should consider the factors like experience and team working to strengthen sustainability-based cultural orientation.

This qualitative research cannot escape limitations. Deconstruction method was used to transcript the collected data; this may have led to unforeseen errors. The research is planned in a particular manner; multiple research designs could not be used. But availability of qualitative findings envisaged between the aspects is meaningful. Finally, this study was based on branches of public, private and foreign banks and the samples were collected from Delhi and NCR region; therefore, non-generalization of these findings is a limitation as well. 
Regardless of the limitations, the study enriches the existing literature. There are many directions that can be pursued with regard to further research. Furthermore, studies can look into other aspects in this work. The geographical range could be widened. Also, a comparative analysis of the organizational culture between public, private sector and foreign banks could be endeavored, which could come out with remarkable outcomes.

\section{Conclusion}

Overall, our word frequency query result indicates that the culture of Indian banking industry prefers good work and working environment, people, managing, involvement and advancements in comparison to all the other factors like policy, bonus, market, commitment, project, etc. It is also noted that bank executives prefer learning, training and team working for their effectiveness.

Our credence is the anticipated organizational culture aspects in this research study that can originate untangling the intricate associations between the two extended literatures (quantitative and qualitative) of organizational culture. In this term, it is likely to reconnoiter the concepts in a prepared and systematic manner. It also empowers scholars to dichotomize the contemporary aspects of organizational culture further.

\section{References}

Aboramadan, M., Albashiti, B., Alharazin, H. and Zaidoune, S. (2019), "Organizational culture, innovation and performance: a study from a non-western context", Journal of Management Development, Vol. 39 No. 4, pp. 437-451.

Adler, N.J. and Graham, J.L. (1989), “Cross-cultural interaction: the international comparison fallacy?", Journal of International Business Studies, Vol. 20 No. 3, pp. 515-537.

Akhavan, P., Sanjaghi, M.E., Rezaeenour, J. and Ojaghi, H. (2014), "Examining the relationships between organizational culture, knowledge management and environmental responsiveness capability", VINE: The Journal of Information and Knowledge Management Systems, Vol. 44 No. 2, pp. 228-248.

Altstedter, A. and Nag, A. (2018), available at: https://www.bloomberg.com/news/articles/2018-02-28/ global-investors-are-rattled-by-india-s-new-season-of-scandal.

Antony, A. and Sanjai, P.R. (2018), available at: https://www.bloomberg.com/news/articles/2018-02-26/ ghosts-of-frauds-past-haunt-indian-jewelers-as-banks-raise-alarm.

Bamel, U.K., Rangnekar, S. and Rastogi, R. (2011), "Managerial effectiveness in Indian organisations: reexamining an instrument in an Indian context", Research and Practice in Human Resource Management, Vol. 19, pp. 69-78.

Bazeley and Jackson (2013), Qualitative Data Analysis with NVivo, Sage Publications, London.

Blackwell, S.S. (2006), "The influence of perception of organizational structure and culture on leadership role requirements: the moderating impact of locus of control and self-monitoring", Journal of Leadership and Organizational Studies, Vol. 12 No. 4, pp. 27-49.

Bloor, G. and Dawson, P. (1994), "Understanding professional culture in organizational context", Organization Studies, Vol. 15 No. 2, pp. 275-295, doi: 10.1177/017084069401500205.

Burns, N. and Grove, S.K. (2005), The Practice of Nursing Research: Conduct, Critique, and Utilization, Elsevier/Saunders, St. Louis, MO.

Calciolari, S., Prenestini, A. and Lega, F. (2018), "An organizational culture for all seasons? How cultural type dominance and strength influence different performance goals", Public Management Review, Vol. 20 No. 9, pp. 1400-1422.

Catana, D. and Catana, A. (2010), "Aspects of transformation of corporate cultures in Romania", II Chemnitzer Ostforum: Transformation of Corporate Cultures in Eastern Germany and Eastern Europe, pp. 21-23.

Denison, D.R. (1990), Corporate Culture and Organisational Effectiveness, John Wiley, New York.

Diwanji, A. (2018), "EY India”, available at: https://www.livemint.com/. 
Dwivedi, S., Kaushik, S. and Luxmi (2014), "Impact of organisational culture on commitment of employees: an empirical study of BPO sector in India”, Vikalpa the Journal of Decision Makers, Vol. 39 No. 3, pp. 77-92.

Fowler, F.J. and Cosenza, C. (2008), "Writing effective questions", in de Leeuw, E.D., Joop, J., Hox, J.J. and Dillman, D.A. (Eds), International Handbook of Survey Methodology, Psychological Press, London.

Furnham, A. and Gunter, B. (1993), "Corporate culture: definition, diagnosis and change”, in Cooper, C.L. and Robertson, I.T. (Eds), International Review of Industrial and Organizational Psychology, Vol. 5, pp. 7-16.

Gordon, G. and Tomaso, N. (1992), "Predicting corporate performance from organizational culture", Journal of Management Studies, Vol. 29, pp. 783-798.

Gurnani (2015), available at: https://www.lawctopus.com/academike/economic-scams-india/.

Harung, H.S., Heaton, D.P. and Alexander, C.N. (1999), "Evolution of organisations in the new millennium", The Leadership and Organisational Development Journal, Vol. 20 No. 4, pp. 198-206.

Hatch, M. (1993), "The dynamics of organizational culture", The Academy of Management Review, Vol. 18, p. 657, doi: 10.2307/258594.

Hofstede, G. (1994), “The business of international business is culture”, International Business Review, Vol. 3 No. 1, pp. 1-14.

Hsieh, H.F. and Shannon, S.E. (2005), "Three approaches to qualitative content analysis", Qualitative Health Research, Vol. 15 No. 9, pp. 1277-1294.

Johnson, R.B. (1997), "Examining the validity structure of qualitative research", Education, Vol. 2 No. 118, pp. 282-292.

Kaid, L.L. and Wadsworth, A.J. (1989), "Content analysis", in Emmert, P. and Barker, L.L. (Eds), Measurement of Communication Behavior, Longman, New York, NY, pp. 197-217.

Kelepile, K. (2015), "Impact of organisational culture on productivity and quality management: a case study in diamond operations unit, DTC Botswana international", Journal of Research in Business Studies and Management, Vol. 2 No. 9, pp. 35-45.

Kilmann, R., Saxton, M. and Serpa, R. (1985), Gaining Control of the Corporate Culture, Jossey-Bass, San Francisco.

Kotter, J.P. and Heskett, J.L. (1992), Corporate Culture and Performance, Free Press, New York, NY. Krippendorff, K. (2012), Content Analysis: An Introduction to its Methodology, Sage, Thousand Oaks, CA.

Leveson, Joiner, T.A. and Bakalis, S. (2009), "Managing cultural diversity and perceived organizational support", International Journal of Manpower, Vol. 30 No. 4, pp. 377-392.

Maxwell, J. (1992), "Understanding and validity in qualitative research", Harvard Educational Review, Vol. 62 No. 3, pp. 279-301.

Mellor, J. (2015), “The world financial review”, available at: http://www.worldfinancialreview.com/?p=4462.

Nazir, N.A. (2005), "Person-culture fit and employee commitment in banks", Vikalpa: The Journal of Decision Makers, Vol. 30 No. 3, pp. 39-51.

Negi, P.S. and Dangwal, R.C. (2019), "Organisational sustainability through culture and managerial effectiveness: an Indian perspective", Journal of Entrepreneurship and Innovation in Emerging Economies, Vol. 5 No. 1, pp. 1-15.

Negi, P.S. and Dangwal, R.C. (2020), "Managerial effectiveness and its correlates in indian banking industry", PSU Research Review: An International Journal, Vol. ahead-of-print No. ahead-ofprint. doi: 10.1108/PRR-05-2018-0014.

Negi, P.S., Dangwal, R.C. and Tomar, Y. (2019), "Sustainability-oriented organizational-culture in Indian service-sector", Organizational Culture, Vol. 19 No. 1, pp. 44-58.

Ojo, O. (2009), "Impact assessment of corporate culture on employee job performance", Business Intelligence Journal, Vol. 2 No. 2, pp. 388-397. 


\section{PRR}

Pathardikar, A.D. and Sahu, S. (2011), "Implications of the organization cultural antecedents on organizational commitment: a study in Indian public sector units", Global Business Review, Vol. 12 No. 3, pp. 431-446.

Peters, T.J. and Waterman, R.H. (1982), In Search of Excellence, Harper \& Row, New York, NY.

Pettigrew, A.M. (1979), "On studying organisational cultures”, Administrative Science Quarterly, Vol. 24, pp. 570-581.

Riivari, E. (2012), “Anna-Maija Lämsä Johanna Kujala Erika HeiskanenThe ethical culture of organisations and organisational innovativeness", European Journal of in Novation Management, Vol. 15 No. 3, pp. 310-331.

Sanjhagi, P.A.M.E., Rezaeenour, J. and Ojaghi, H. (2014), "Examining the relationship between organisational culture, knowledge management and environmental responsiveness capability", VINE: The Journal of Information and Knowledge Management Systems, Vol. 44 No. 2, pp. 228-248.

Schein, E.H. (1990), "Organisational culture”, American Psychologist, Vol. 45 No. 2, pp. 109-119.

Sekaran, U. (2003), Research Methods for Business A Skill-Building Approach, 4th ed., John Wiley \& Sons, Hoboken.

Singh, A.K. (2011), "HRD practices and managerial effectiveness: role of organisation culture", Indian Journal of Industrial Relations, Vol. 47 No. 1, pp. 138-148.

Taylor, J. (2008), "Organizational influences, public service motivation and work outcomes: an Australian study", International Public Management Journal, Vol. 11 No. 1, pp. 67-88.

Tripathi, S. and Tripathi, N. (2009), "Influence strategies and organisational success: moderating effect of organisational culture”, Indian Journal of Industrial Relations, Vol. 45 No. 2, pp. 213-228.

Uzkurt, R.K., Kimzan, H.S. and Eminoğlu, G. (2013), "Role of innovation in the relationship between organizational culture and firm performance", European Journal of Innovation Management, Vol. 16 No. 1, pp. 92-117.

Zikmud, W.J., Babin, B.J., Carr, J.C., Adhikari, A. and Griffin, M. (2013), Business Research Methods, 8th ed., F.I.E: Cengage Learning, New Delhi.

\section{Further reading}

Great Place to Work Institute (2011), available at: www.greatplacetowork.com/what_we_do/ employee_survey.php.

\section{Appendix}

Table A1.

Demographic characteristics of the managers

\begin{tabular}{|c|c|c|c|c|c|c|c|c|}
\hline \multirow{2}{*}{$\begin{array}{l}\text { Position } \\
\text { Top and middle } \\
\text { level }\end{array}$} & \multicolumn{3}{|c|}{ Gender } & \multirow{2}{*}{\multicolumn{2}{|c|}{$\begin{array}{l}\text { Category of bank } \\
\text { Private } \\
\text { banks }\end{array}$}} & \multirow[b]{2}{*}{$\begin{array}{c}\text { Foreign } \\
\text { banks }\end{array}$} & \multicolumn{2}{|c|}{ Location } \\
\hline & Male & Female & Others & & & & Delhi & NCR \\
\hline 96 & 79 & 17 & - & 32 & 35 & 29 & 57 & 39 \\
\hline
\end{tabular}

\section{Corresponding author}

Pooja Singh Negi can be contacted at: mrtpoojasingh@gmail.com

For instructions on how to order reprints of this article, please visit our website:

www.emeraldgrouppublishing.com/licensing/reprints.htm

Or contact us for further details: permissions@emeraldinsight.com 